\title{
HTLV-3 and HTLV-4 antisense proteins enhance the transactivation potential of several Jun family members through interaction via their bZIP-like domain
}

\author{
Émilie Larocque ${ }^{1 *}$, Charlotte André-Arpin ${ }^{2}$, Jean-Michel Mesnard ${ }^{2}$, William M Switzer ${ }^{3}$, Benoit Barbeau ${ }^{1}$ \\ From 16th International Conference on Human Retroviruses: HTLV and Related Viruses \\ Montreal, Canada. 26-30 June 2013
}

HTLV-3 and HTLV-4 are two recently identified viruses closely related to HTLV-1, which have not yet been linked to any diseases. Similarly to HTLV-1 and HTLV2 , which both express antisense transcript-derived HBZ and APH-2, respectively, HTLV-3 and HTLV-4 harbor antisense genes termed $\mathrm{APH}-3$ and $\mathrm{APH}-4$. These two encoded proteins contain an atypical bZIP domain but are still able to down-regulate Tax-mediated LTR activation, alike HBZ and APH-2. Since HBZ and APH-2 affect Jun-dependent transcription differently, our goal was to assess the impact of APH- 3 and APH- 4 on the transactivation potential of Jun family members. Co-IP experiments first showed that both APH-3 and APH-4 interacted with all tested Jun members. Jun/APH complexes significantly enhanced Jun-dependent transactivation of the human collagenase promoter containing a single AP-1 binding site as well as a construct bearing a minimal promoter and AP-1-binding sites. APH-3 and $\mathrm{APH}-4$ deletion mutants and point mutations of specific leucine residues demonstrated that this functional interaction was mediated by the bZIP-like domain. Using a construct with a minimal promoter bearing GAL4-binding sites and $\mathrm{APH}-3 / \mathrm{APH}-4$ expression vectors fused to the GAL4 DNA binding domain, we further showed that, in contrast to HBZ, APH-3 and APH-4 did not contain an activation domain. These results highlight the varying capacity of different HTLV-encoded antisense proteins to act upon transactivation mediated by Jun transcription factors. Taking into account the

\footnotetext{
* Correspondence: larocque.emilie@gmail.com

'Département des Sciences Biologiques and Centre de Recherche BioMed,

Université du Québec à Montréal, Montréal (Québec) Canada

Full list of author information is available at the end of the article
}

previously reported association between $\mathrm{HBZ}$ and ATL development, determining the functional differences of these HTLV antisense proteins could contribute in better understanding this association.

\section{Authors' details}

'Département des Sciences Biologiques and Centre de Recherche BioMed, Université du Québec à Montréal, Montréal (Québec) Canada. ${ }^{2}$ Université Montpellier 1, Centre d'Etudes d'Agents Pathogènes et Biotechnologies pour la Santé, CNRS, UM5236, Montpellier, France. 'aboratory Branch, Division of HIV/AIDS Prevention, National Center for HIV, STD, and TB prevention, Centers for Disease Control and Prevention, Atlanta, GA, USA.

Published: 7 January 2014

doi:10.1186/1742-4690-11-S1-072

Cite this article as: Larocque et al: HTLV-3 and HTLV-4 antisense proteins enhance the transactivation potential of several Jun family members through interaction via their bZIP-like domain. Retrovirology 2014 11(Suppl 1):072.

Submit your next manuscript to BioMed Central and take full advantage of:

- Convenient online submission

- Thorough peer review

- No space constraints or color figure charges

- Immediate publication on acceptance

- Inclusion in PubMed, CAS, Scopus and Google Scholar

- Research which is freely available for redistribution

Submit your manuscript at www.biomedcentral.com/submit
() Biomed Central 